\title{
Turismo como Vetor de Desenvolvimento Local: um olhar através das ideias de Theodor Adorno e Max Horkheimer
}

\author{
Tourism as a Vector of Local Development: a look through the ideas of Theodor Adorno \\ and Max Horkheimer
}

\section{Turismo Como Vector De Desarrollo Local: una mirada a través de las ideas de Theodor Adorno y Max Horkheimer}

\author{
Alba de Oliveira Barbosa Lopes ${ }^{1}$ \\ Dinah dos Santos Tinôco ${ }^{2}$ \\ Richard Medeiros de Araújo ${ }^{3}$
}

\begin{abstract}
Resumo
Este ensaio procura compreender a relação entre turismo e desenvolvimento. Para tanto, se apóia em uma pesquisa bibliográfica e dá ênfase especial as ideias de Theodor Adorno e Max Horkheimer. Embora esses autores não tenham discutido a temática do turismo, mas, as suas ideias relativas à valorização da ciência positivista e sua influência para a legitimação dos dados e fatos econômicos que apóiam investimentos governamentais, podem contribuir com uma reflexão crítica. Destacam-se, também, as suas discussões sobre Indústria Cultural, onde a mercantilização de atividades culturais e a valorização do prazer contribuem para a acriticidade dos homens. Os países em desenvolvimento são impulsionados a direcionar suas estratégias para um crescimento sócio-econômico no sentido de dinamizar setores capazes de gerar emprego e estimular a melhoria da qualidade de vida da população. Este artigo pressupõe que o questionamento do potencial turístico enquanto vetor de desenvolvimento não deve ser negado, supõe, contudo, que as bases do modelo de desenvolvimento devem ser melhor analisadas para além da racionalidade instrumental, de forma a evitar uma percepção acrítica da atividade turística, como também, a adoção inapropriada de modelos de desenvolvimento que não atendem às necessidades da comunidade local.
\end{abstract}

Palavras-chave: turismo; desenvolvimento; indústria cultural.

\footnotetext{
${ }^{1}$ Doutoranda em Administração pela Universidade Federal do Rio Grande do Norte (UFRN). Graduada e mestre em Administração pela Universidade Federal de Pernambuco (UFPE). Professora do Instituto Federal de Pernambuco (IFPE). E-mail: albabarbosa@ig.com.br.

2 Pós-doutora pela Universidade de Versailles Saint Quentin, França. Doutora e mestre em Urbanismo pela Universidade de Paris XII. Graduada em Economia pela UFRN onde é Professora Associada no Departamento de Ciências Administrativas. E-mail: dinahtinoco@uol.com.br.

${ }^{3}$ Doutorando em Administração pela UFRN. Mestre em Administração pela Universidade Federal da Paraíba (UFPB). Bacharel em Administração pela Universidade Potiguar. Professor e Coordenador do Curso Superior Tecnológico em Gestão Comercial da Faculdade de Ciências, Cultura e Extensão do RN. E-mail: richardmaraujo@uol.com.br.
} 


\begin{abstract}
This essay seeks to understand the relationship between tourism and development. For that, it relies in a bibliographical research and emphasizes the ideas of Theodor Adorno and Max Horkheimer. Although this authors have not discussed the thematic of tourism, their ideas related to make valuable positivist science and its influence to legitimate the data and economical facts that support governmental investments, can contribute to a critical reflection. Highlights also to their discussions about Cultural Industry, where merchandizing of cultural activities and making leisure valuable contribute to criticism of men. The developing countries are pushed to direct their strategies to an social-economic growth in the sense of optimize sectors capable of generating jobs and stimulate population's quality of life. This article assumes that questioning touristic potential whilst vector of development should not be denied. It assumes, after all, that the basis of the development model should be best analyzed to beyond instrumental rationality, in order to avoid a critical perception of touristic activity, as well as inappropriate adoption of development models that don't attend the needs of local community.
\end{abstract}

Keywords: tourism; development; cultural industry.

\title{
Resumen
}

Este ensayo busca comprender la relación entre turismo y desarrollo. Por lo tanto, apoyase en una investigación bibliografica dando especial énfasis en las ideas de Theodor Adorno y Max Horkheimer. Aunque esos autores no tengan discutido la temática del turismo, pero, sus ideas relativas a la valoración de la ciencia positivista y su influencia para la legitimación de los datos y factos economicos que apoyan inversiones gubernamentales, pueden contribuir con una reflexión crítica. Se destacan, además, las discusiones sobre la Industria Cultural, donde la mercantilización de actividades culturales y la valoración del placer contribuyen para la creatividad de los hombres. Los paises en desarrollo son impulsados a conducir sus estrategias para un crecimiento socio-economico en el sentido de dinamizar sectores capaces de generar empleo y estimular la mejora de calidad de vida a la población. Este artículo presupone que la cuestión del potencial turístico como vector de desarrollo no debe ser negado, supone, sin embargo, que las bases del modelo de desarrollo deben ser mejor analizadas para más allá de la racionalidad instrumental, de forma a evitar una percepción acrítica de la actividad turística, como igual, la adopción inapropiada de los modelos de desarrollo que no cumple las necesidades de la comunidad local.

Palabras claves: turismo; desarrollo; industria cultural

\section{Introdução}

O homem desloca-se no território desde o início dos tempos, quando os primitivos percorriam grandes distâncias em busca de comida e agasalho necessários à sobrevivência. Ao longo da história, as pessoas viajam para satisfazer necessidades comerciais, educacionais, religiosas, 
econômicas, de domínio de territórios, saúde, etc. O turismo de massa, contudo, se ampliou em todo o planeta no século XXI, onde poucos países estão fora da área do turismo, se não provisoriamente em razão de guerras ou de catástrofes. (CAZES; COURADE, 2004).

O turismo, enquanto fenômeno de massa, foi possível em decorrência de diversos fatores que possibilitaram a estabilidade econômica e política para o desenvolvimento e expansão das viagens e o barateamento dos custos de promoção dos serviços turísticos, na segunda metade do século XXI. Fatores como: a paz prolongada em parte da Europa e nos Estados Unidos; redução das jornadas de trabalho e criação das férias anuais remuneradas; consolidação da classe média com aumento do poder aquisitivo de amplas camadas da população; avanços tecnológicos na comunicação e no transporte, permitindo viagens mais cômodas e rápidas e redução progressiva dos preços, contribuíram para a intensificação das viagens e para a ampliação do acesso de grupos antes excluídos do processo turístico.

O fenômeno turístico é considerado como um projeto de sociedade que se apropria de espaços e os transforma segundo normas e valores que lhe são próprios e que transcendem os limites espaciais. As escolhas de quais territórios devem tornar-se turísticos são bastante seletivas e são resultados de uma intenção construída coletivamente (DUHAMEL; VIOLIER, 2009). Para muitos autores e gestores públicos e privados, o fenômeno turístico passa a ser fundamental no processo de desenvolvimento local, notadamente após a Segunda Guerra Mundial. A partir da década de 50, os países da América Latina passaram a recorrer a financiamentos para impulsionar o turismo em prol do desenvolvimento. Essa associação com o desenvolvimento é feita tomando como pressuposto que a atividade tem potencial para corrigir desigualdades sociais, através da geração de emprego e renda e do seu efeito multiplicador da receita gerada.

De forma concomitante, por meio de ideias fundamentadas no referencial de desenvolvimento via crescimento econômico, organismos internacionais, como o Banco Mundial (BIRD), Organização das Nações Unidas (ONU) e a Organização de Cooperação e de Desenvolvimento Econômico (OCDE) passaram a disseminar a ideia e a apoiar ações no sentido de estimular o desenvolvimento via turismo, especialmente em regiões economicamente carente de recursos financeiros, mas com abundantes recursos naturais, culturais e ambientais com grande potencial de interesse turístico. Modelos de gestão do 
turismo desenvolvidos em países com realidades econômicas, políticas e sociais distintas começaram a ser incorporados em regiões tropicais litorâneas baseados na sinonímia entre o desenvolvimento e crescimento econômico e na utilização de modelos e experiências "de sucesso" dos países desenvolvidos para que essa situação, de forma evolutiva, fosse atingida pelos demais.

Esses países por não possuírem recursos financeiros suficientes, poderiam aproveitar os recursos naturais e culturais abundantes, como também o contingente de mão-de-obra desempregada e barata para investir na atividade turística. Os estudos publicados no período faziam afirmações contundentes sobre o turismo, como pode ser visto em Ballester Ros (1967, p. 80),

[...] En 1963, las Naciones Unidas han recomendado que se otorgue prioridad a la asistencia técnica en el sector del turismo por su importancia como medio de reforzar la política de crecimiento económico en los países en vías de desarrollo, ya que el turismo estimula las inversiones, constituye un medio de procurarse divisas y es una fuente de creación de empleo, estimula la movilidad social y la reconversión de profesiones para atender a las necesidades de servicios derivadas del turismo.

Se por um lado, o turismo pode ter impactos bastante positivos na balança de pagamentos, na geração de emprego e renda e na valorização do lugar, conforme argumentos de incentivo ao desenvolvimento da atividade aos países membros da Organização Mundial do Turismo (OMT), o mesmo, de acordo com estudos do BIRD $^{4}$ quando mal planejado e regulamentado, pode apresentar efeitos e externalidades negativas na localidade receptora e na economia nacional.

Apesar de sua crescente importância na economia de muitas regiões, vários estudos como o de Archer e Cooper (2002), Beni (2000), Coriolano (1999) e Lage e Milone (2000) têm identificado problemas diretamente ou não, gerados ou agravados pelo turismo nos âmbitos social e ambiental, notadamente quando este é desenvolvido de forma a desconsiderar as necessidades da população e governo local e sem respeitar os limites de capacidade de carga

\footnotetext{
${ }^{4}$ Estudos publicados em forma de livros como as obras de De Kadt (1979) e Arrones (1992) que destacaram as contradições do desenvolvimento turístico nas regiões do México, Caribe e Espanha.
} 
do destino ${ }^{5}$, voltando-se tão somente para a adaptação do lugar as exigências dos visitantes e aos interesses do mercado.

Baldi e Lopes (2006) destacam a necessidade de considerar criticamente a visão hegemônica de que o turismo leva diretamente ao desenvolvimento local. Para os autores, a construção do turismo está posta sem grandes reflexões. Especialmente a partir da década de 90, o turismo passou a ser apontado como a "alternativa da vez" para o problema do desenvolvimento dos países do hemisfério sul. Especialmente no Nordeste do Brasil, as ações governamentais valorizaram a função turística do território brasileiro como uma das maneiras de se atingir o desenvolvimento.

Para ampliar a análise sobre a temática, este artigo recorre às ideias de Theodor Adorno e Max Horkheimer, entre outros autores, com vistas a compreender de forma mais crítica a adoção do turismo enquanto modelo de desenvolvimento de localidades. Adorno e Horkheimer não discutiram a temática do turismo, mas suas ideias relativas à valorização da ciência positivista que naturaliza os fenômenos sociais, desprezando o contexto histórico e sua influência para a legitimação dos dados e fatos econômicos que apóiam investimentos turísticos em muitos governos podem contribuir para o aumento da reflexão sobre o tema. São importantes também as discussões sobre Indústria Cultural, onde existe a mercantilização de atividades substantivas e do fornecimento de situações de prazer que contribuem para a diminuição da criticidade dos homens em relação ao seu lugar na sociedade.

Estudar turismo é importante pela relevância dessa atividade na sociedade. Salto (1998) destaca que as previsões acerca do crescimento do turismo são bastante otimistas e que, cada vez mais, ele contribuirá para o aumento do Produto Interno Bruto de muitos países. Importante, em oposição ao crescimento do turismo, a incipiente representatividade da temática na área de pesquisa em administração, apesar do crescimento no país e do potencial de impactos positivos e negativos da atividade.

Barbosa et al (2008) fizeram uma análise bibliométrica da produção científica em turismo no principal congresso de administração no país, o Encontro Nacional de Pós-graduação em Administração (Enanpad) e verificaram que a temática representa menos de $1 \%$ dos artigos

\footnotetext{
${ }^{5} \mathrm{O}$ conceito se refere ao número máximo de turistas que podem ser hospedados em uma destinação geográfica específica (WILLIAMS; GILL, 2002).
} 
publicados nos anos de 2003 a 2007. O turismo não despertou o interesse de pesquisa na área de administração, mesmo tendo impactos consideráveis na economia, na gestão das cidades e na vida social. Apesar de não ter sido foco deste estudo, os autores perceberam também a predominância de artigos funcionalistas em relação ao tema que pode contribuir para uma análise superficial do turismo.

\section{Teoria Tradicional e Teoria Crítica}

Adorno e Horkheimer fazem parte da chamada Escola de Frankfurt que, conforme Freitag (1990) refere-se simultaneamente a um grupo de intelectuais e a uma teoria social ${ }^{6}$. O foco do pensamento dos intelectuais dessa escola apesar das inúmeras diferenças e especificidades, era a teorização de uma sociedade que permitisse a construção de um conhecimento emancipatório, o qual conduziria à felicidade humana.

No artigo Teoria Tradicional e Teoria Crítica, Horkheimer (1980) destaca o conflito existente entre o positivismo e a dialética. $\mathrm{O}$ autor contrapõe o pensamento de Descartes (teoria tradicional) ao de Marx (teoria crítica) denunciando o caráter funcionalista, conservador e restrito do primeiro e exaltando a dimensão subjetiva, humanística e emancipatória do segundo. Ainda segundo o autor, não se trata de descartar a teoria tradicional, mas de entender suas limitações, especialmente no que tange a possibilidade de redução dos fenômenos sociais a fatos dados, estáticos, encaixando-os "perfeitamente" em sistemas teóricos pré-definidos.

A crítica de Horkheimer se dá pela percepção da racionalidade instrumental, que está diretamente ligada à ação e supõe a possibilidade do cálculo utilitário das conseqüências, como base da ciência positivista. Percebe-se que a teoria baseada na racionalidade instrumental não oferece meios para a criação de espaços sociais onde os indivíduos possam se desenvolver; a racionalidade passa a voltar-se para o mercado e não à psique humana. $\mathrm{O}$ homem é considerado, ou melhor, é reduzido, a uma criatura que calcula, sendo difícil para

\footnotetext{
${ }^{6}$ O Instituto de Pesquisas Sociais (Institut für Sozialforschung), foi criado em Frankfurt por um decreto do Ministério de Educação de 3 de fevereiro de 1923. Tratava-se de uma Escola de Filosofia social nascida da reorganização do Instituto de Pesquisa Social por Horkheimer, em 1931. Esse instituto foi obrigado de deixar a Alemanha durante o nazismo, tendo permanecido através de suas filiais principalmente em Paris e Genebra, retornado para a Alemanha apenas em 1950 (ASSOUN, 1990).
} 
ele considerar outros aspectos que não estejam ligados ao mercado e as organizações. $\mathrm{O}$ homem é aquilo que ele representa para as organizações, ele passa a ser um meio para o lucro. Conforme Adorno e Horkheimer (1985), ao invés de conduzir à produção de um conhecimento que visasse à emancipação do espírito humano, a razão conduziu à técnica e à ciência positivista, que reforçaram as amarras que o atavam. A razão instrumental, ao contrário de libertar, contribuiu para a repressão e converteu-se em razão alienada, que se desviou do objetivo emancipatório. Os referidos autores buscavam utilizar a razão como instrumento de libertação para alcançar a autonomia do homem.

Essa questão também é abordada por Alberto Guerreiro Ramos, autor brasileiro crítico, mas não frankfurtiano, em sua obra "A Nova Ciência das Organizações", publicada em 1981, que critica a predominância da racionalidade instrumental. Para realizar sua crítica, o autor retoma os sentidos antigo e moderno da razão. Antigamente, razão era entendida como a habilidade de distinguir entre o bem e o mal, o falso e o verdadeiro. Atualmente, a razão serve para legitimar a sociedade contemporânea, legitimar o cálculo utilitário das conseqüências.

A racionalidade instrumental está ampliando seu espaço na sociedade, o que faz com que os aspectos econômicos e financeiros sejam supervalorizados e considerados com grande ênfase nas decisões, inclusive governamentais. Nas sociedades industriais, a lógica da racionalidade instrumental, que amplia o controle da natureza, ou seja, "o desenvolvimento das forças produtoras, se tornou a lógica da vida humana em geral”' (RAMOS, 1989, p. 12). Nas relações sociais e não apenas no âmbito organizacional, busca-se a eficiência e a eficácia em detrimento dos valores humanitários. Guerreiro Ramos propõe a sobreposição da racionalidade substantiva para revalorizar aspectos humanos na sociedade e, conseqüentemente, nas organizações.

Conforme Bronzo e Garcia (2000), ao discutirem as bases epistemológicas do pensamento administrativo convencional, qualquer teoria expressa os valores dominantes em contextos históricos específicos. O fenômeno é tido como normal. No entanto, do ponto de vista epistemológico e metodológico, os estudos da ciência da administração (e no caso deste artigo, administração do turismo) poderiam ampliar suas análises ao se distanciarem de uma abordagem apenas instrumental e incorporarem uma perspectiva histórica, crítica, plural e dialética. 
Adorno e Horkheimer criticam a noção cientificista, acrítica, a-histórica e neutra (ou aparentemente neutra) da teoria tradicional baseada no positivismo. Conforme Horkheimer (1980, p. 155) a "gênese social dos problemas, as situações reais, nas quais a ciência é empregada e os fins perseguidos em sua aplicação, são por ela mesma considerada exteriores". Para o autor, no momento em que o pensamento teórico deixa de captar, estudar, analisar os fenômenos exteriores, estranhos ao objeto, e se focam nos problemas complexos em suas conexões com o mundo, o pesquisador tem acesso a novos problemas e pode modificar conceitos antigos. Na teoria crítica, portanto, o homem é o elemento central de análise, mas não isolado de seu contexto, ela tem como objeto os homens como produtores de todas as suas formas históricas de vida. Não se investiga, portanto, fazendo meras constatações e previsões, mas a relação da produção humana com o material dos fatos.

A proposta da teoria crítica é retomar a humanidade da razão que foi perdida. A razão humana foi substituída pela razão técnica de modo que os aspectos econômicos são tidos como os mais importantes no mundo capitalista. Para Freitag (1990) todas as áreas da vida foram invadidas pelas ideias de exploração de negócios, até mesmo a cultura, último reduto dos operários. Tudo se torna negócio e o capitalismo, segundo Santos Filho (2005, p. 31), "organiza e mercantiliza o lazer, proporcionando momentos idiotizantes e descomprometidos com o cotidiano". Ainda conforme o autor, para o capitalismo, o turismo é uma mercadoria que deve ser otimizada para o acúmulo de capital e pouco voltada para o bem-estar da população, já que o uso de tempo livre não obedece a nenhuma ética e princípios, mas tão somente à necessidade do capital.

\section{Indústria Cultural}

No período de consolidação da industrialização e da expansão da lógica capitalista Adorno e Horkheimer publicam o artigo "A indústria Cultural: o iluminismo como mistificação das massas, em 1947. E discute como o mercado tem transformado os bens culturais em mercadorias. Para eles, a reprodução de uma obra de arte levaria a degradação do bem, descaracterizando-o enquanto instrumento para o culto ao espírito. Conforme Adorno (1971, p. 288) “as mercadorias culturais da indústria se orientam segundo o princípio da 
comercialização e não segundo seu próprio conteúdo e sua figuração adequada". Toda a práxis da indústria cultural transfere, sem mais, a motivação do lucro às criações espirituais.

Os frankfurtianos, apesar de possuírem uma visão negativa da questão da popularização dos bens culturais, parecem não serem contra ao acesso de grande número de pessoas à cultura, mas criticavam a subordinação da cultura ao mercado e a autodestruição do esclarecimento da humanidade. Este artigo permite essa discussão uma vez que a cultura do lugar com todas as suas manifestações (festas, rituais, artesanatos, celebrações religiosas, etc.) são elementos importantes na promoção da atividade turística.

Se for ampliada a crítica de Adorno e Horkheimer, uma vez que originalmente eles não tratavam do turismo, pode-se inferir que o turismo pode estimular à comercialização de formas culturais do lugar que perderiam seu(s) significado(s) original(is), transformado(s) em mero(s) produto(s) comercializado(s). Inclusive o contato de culturas distintas pode provocar o processo de aculturação da comunidade receptora, fazendo com que economias tradicionais e rituais existentes percam o sentido. Bacal (2003, p. 92) contribui para a discussão ao destacar que,

é preciso temer ${ }^{7}$ a indústria dos lazeres, que se utiliza da valorização das atividades de lazer como meio para obtenção de lucro e, como se sabe, a exploração comercial é um condicionante que poderá converter as atividades de lazer em condutas estandarlizadas, estereotipadas e pré-fabricadas, que, de fato, respondem mais às necessidades daquela indústria do que aos reais desejos e exigências das pessoas.

Além do aspecto econômico, as discussões da Indústria Cultural conduzem a inquietação, pois, segundo Adorno e Horkheimer (1985), a mercantilização da cultura impede a formação de indivíduos autônomos ao conduzir os homens a uma sensação confortável de que o mundo está em ordem num tipo de satisfação compensatória. Ainda segundo os autores,

divertir-se significa estar de acordo. [...] Divertir significa sempre: não ter que pensar nisso, esquecer o sofrimento até mesmo onde ele é mostrado. A impotência é a sua própria base. É na verdade uma fuga, mas não, como

\footnotetext{
${ }^{7}$ Os autores deste artigo preferem trocar a palavra temer por ter cuidado, precaução, mas concordam com a continuação da citação.
} 
afirma, uma fuga da realidade ruim, mas da última ideia de resistência que essa realidade ainda deixa subsistir (ADORNO; HORKHEIMER,1985, p. 119).

As horas de lazer, portanto, proporcionariam um sentimento de satisfação aos envolvidos que contribuem para controlar as ações dos mesmos, onde para perpetuar o prazer, não devem mais exigir esforço, reflexão. $\mathrm{O}$ espectador seria destituído de pensamento próprio. Adorno e Horkheimer (1985) referem-se especialmente aos instrumentos de comunicação, mas suas ideias também podem contribuir para a análise do turismo. O turismo pode conduzir também a esse sentimento de satisfação e de não reflexão. Conforme Urry (1996), o turismo de massa promove viagens em grupos onde os turistas encontram prazer em atrações inventadas com pouca ou nenhuma autenticidade, gozam com credulidade de "pseudos-acontecimentos" e não levam em consideração o "mundo real" em torno deles. As comunidades são levadas a produzir apresentações para a observação turística que são consumidas sem grandes reflexões pois já foram decodificadas pelos eficientes mecanismos de propaganda e marketing e tornados prontos para o consumo.

As ferramentas de marketing voltadas ao turismo tendem a influenciar o comportamento de compra dos turistas trabalhando a subjetividade e lançando a imagem de felicidade no consumo de bens e produtos que, em certo sentido, são desnecessários. São consumidos porque proporcionam, segundo essas ferramentas, experiências prazerosas, diferentes daquelas que as pessoas encontram no trabalho estressante. No entanto, são experiências, geralmente, superficiais, pois conforme Bacal (2003), o turista com sua câmera fotográfica ou sua máquina de filmar, não tenta tirar o prazer de usufruir a paisagem na experiência em foco, mas consumi-la depois, através do que foi captado pela câmera. O importante não é o enriquecimento das próprias vivências, mas as provas (fotos, filmagens) do que se viu e por onde se passou.

Fressato (2007) discorre que a indústria do prazer acaba por planejar a diversão coletiva. O lazer se transforma na continuidade da vida, assim esvazia a vida e difunde uma ideologia, ocupando o espaço de lazer e de diversão do trabalhador assalariado, recompondo suas energias para mais um dia de trabalho, sem permitir que pense sobre a realidade em que vive. Ainda conforme Santos Filho (2005) a sociedade capitalista organiza e determina lazer do 
alheio, inundando o mercado com a venda do lúdico. Esses lazeres podem ser idiotizantes e não possuírem nenhum compromisso com o cotidiano.

Freitag (1990) destaca, ainda na discussão da ciência e da técnica, a produção de bens segue uma lógica técnica e mercantil e não à lógica das necessidades reais dos homens. Ou seja, produz-se ou oferece-se aquilo que dá lucro e não aquilo que os homens realmente necessitam e gostariam de usar. Ser turista é uma das características da experiência moderna e é algo que confere status ao indivíduo que viaja. E, conforme Krippendorf (1989), para os que não viajam, ficar em casa pode parecer difícil de justificar sem que haja uma perda de prestígio social.

Decerto que o turismo, no Brasil, ainda é um lazer para "privilegiados", com poder aquisitivo mediano a elevado, no entanto, são percebidas ações no sentido de massificar a atividade. No país, por exemplo, o Plano Nacional de Turismo 2007-2010 tem como um de suas metas promover o turismo como um fator de inclusão social, por meio da geração de trabalho e renda e pela inclusão da atividade na pauta de consumo de todos os brasileiros, conforme pode ser visto no discurso ex-Ministra de Turismo, Marta Suplicy abaixo:

O Plano Nacional de Turismo - PNT 2007/2010 - Uma Viagem de Inclusão, que aqui apresentamos, traz uma série de estratégias e medidas que vão representar um importante estímulo ao mercado interno. São propostas que abrem as portas do turismo nacional para que todos os brasileiros possam se beneficiar desse mercado. Seja como turista, como empregado, como prestador de serviço, seja como empresário. Seja por meio de cursos de qualificação profissional, da geração de novos empregos, da incorporação das camadas de mais baixa renda como clientes do mercado turístico, seja pela adoção de políticas segmentadas para aposentados, trabalhadores e estudantes. Enfim, o turismo interno será estimulado e abrirá novas portas para a inclusão social (BRASIL, 2007a, p. 7).

Com a inclusão de aposentados, num primeiro momento; estudantes e trabalhadores de baixa renda, posteriormente; o governo visa minimizar os efeitos da sazonalidade ao aumentar as taxas de ocupação da baixa estação com esses públicos. Essa ação também pode contribuir para, conforme exposto anteriormente, reduzir o desconforto da situação de exclusão, não apenas da atividade turística, mas de todos os âmbitos da sociedade e contribuir para a sua 
conformação. O discurso exposto acima, parte do pressuposto de que, como consumidores, as pessoas estavam excluídas do processo por falta de recursos financeiros.

Conforme exposto em Barbosa et al (2008a), a necessidade de construção de uma sociedade democrática e inclusiva é um consenso, mas a questão não deve passar unicamente pela esfera monetária. Até que ponto a infraestrutura turística está apta a receber os portadores de deficiências, os analfabetos, os pobres, as comunidades rurais, as comunidades indígenas e tantos outros segmentos carentes de inclusão? Além disso, se o turismo de massa é uma atividade capitalista por natureza, a exclusão não é uma externalidade, mas um elemento fundamental para a manutenção do mesmo.

Um exemplo do que já foi discutido até o momento é a Política de Turismo do governo do Estado de Pernambuco, nordeste do Brasil, com o nome: Pernambuco para o Mundo e que tem prazo de execução de 12 anos (2008-2020). Em consonância com o Plano Nacional de Turismo busca diversificar e interiorizar o turismo na região como forma de "dar alegria, informação e lazer a quem nos visita, mas também beneficiar a população de todas as regiões do Estado" (PERNAMBUCO, 2008).

A ideia de integração faz parte, como pode ser visto, do discurso do, então, governador Eduardo Campos, no entanto, tomando com base as ações a ser desenvolvidas no Arquipélago de Fernando de Noronha percebe-se que a intenção é valorizar o atrativo perante o mercado. O Plano, partindo do pressuposto que a atividade em Noronha é prejudicial ao ecossistema e aos empreendimentos locais, informa que irá privilegiar um turismo mais consciente, mais qualificado, onde os turistas poderão usufruir dos atrativos de forma mais responsável, não priorizando o turismo de sol e praia apenas.

As ações, no entanto, estão em desacordo com a proposta, pois atrela a qualificação dos turistas ao seu poder aquisitivo. As tarifas para visitação da ilha que já são altas para a grande maioria dos pernambucanos e brasileiros ficarão mais elevadas através da estagnação num alto patamar de preços praticados por equipamentos turísticos, tarifas aéreas com valor acima da média nacional, aumento no valor da taxa ambiental, etc. O plano ainda destaca a atuação e benefícios para o trade turístico: 
sensibilizados acerca de necessidade de manutenção de um alto patamar de preços no destino para que o público visitante de Noronha passe a ser um de mais alta qualidade de visitação e com maior poder aquisitivo, deixando na ilha maior volume de divisas com resultados para seus habitantes, para o empresário e para os agentes do turismo local [...] (PERNAMBUCO, 2008, p. 25).

A lógica positivista parece reforçar as ações governamentais. No caso do turismo, os dados estatísticos produzidos e divulgados pelo Ministério do Turismo, pela FGV - Fundação Getúlio Vargas e/ou pelo IBGE - Instituto Brasileiro de Geografia e Estatística servem para justificar um maior investimento em turismo, pois explicam, dentro do paradigma positivista, que turismo conduz ao aumento de emprego e renda e que o Brasil ainda tem potencial a ser explorado. Entretanto, qual a natureza desses empregos? A renda que está sendo gerada é distribuída de forma equitativa? As comunidades estão tendo acesso às decisões relativas ao uso dos equipamentos turísticos? De que forma está havendo a interação entre as comunidades receptoras e os turistas? Como o meio ambiente está sendo preservado? As séries estatísticas não focam isso, visto se situarem na lógica de mercado que contribui para o agravamento das contradições da sociedade, mesmo quando, em seus discursos, prometem o improvável: felicidade e prosperidade ao alcance de todos.

Freitag (1990) retrata que a ciência não é neutra e que a ciência e a tecnologia transformaramse em dominação econômica e política no interesse de acumulação de capital. Para a autora, a partir do momento em que a ciência e a técnica promovem o "progresso", desejado e aplaudido por todos, elas mesmas legitimam o sistema capitalista, desativando o conflito de classes e silenciando as reivindicações por um sistema político menos alienado. A dimensão emancipadora, crítica, transformadora foi sufocada, porque como forças produtivas, estão hoje a serviço do capital.

\section{Turismo e Desenvolvimento: uma relação óbvia?}

Conforme Britton (1992) existe a tendência dos estudos que versam sobre turismo e desenvolvimento focarem apenas na relação custo-benefício e descreverem de forma imprecisa os impactos sócio-culturais e questões técnicas sobre fluxo de turistas e impactos regionais do mesmo. Esse fato contribui para a análise limitada do turismo que desconsidera o 
contexto político e histórico do desenvolvimento. Apesar dos benefícios econômicos citados e excessivamente explorados pela literatura da área, o turismo deve ser analisado e desenvolvido sobre uma perspectiva crítica, pois também é um fenômeno social, político, cultural, ambiental, geográfico e histórico.

Especialmente na segunda metade do século XX, o turismo de massa passou a ser incorporado ao plano de desenvolvimento de muitas regiões sem uma análise mais cuidadosa dos impactos decorrentes da atividade. Era analisado apenas o potencial de benefícios econômicos e visto como uma saída adequada para o desenvolvimento especialmente das regiões subdesenvolvidas. O subdesenvolvimento constituía um estágio para o desenvolvimento e não uma situação estrutural decorrente, dentre outros fatores, da submissão e subserviência desses países, em períodos anteriores, a países imperialistas. O turismo era, e ainda é em muitas regiões, uma promessa de saída da situação depreciativa e de escassez existente.

Conforme Salto (1998), os países do hemisfério Sul estariam em condições de oferecer ao mercado internacional recursos turísticos, sem grandes necessidades de investimentos. A adoção do turismo iria ajudar esses países a alcançar a modernização e diversificar seu aparato produtivo. Crick (1992) retrata, inclusive, que o turismo era visto como o "maná dos céus", em referência ao alimento enviado por Deus ao seu povo, relatado na Bíblia. O turismo constituia assim o "alimento" que iria impulsionar o desenvolvimento através da entrada de divisas dos visitantes estrangeiros, sem grandes investimentos, pois estes buscavam os recursos naturais e culturais que já estavam disponíveis; e possibilitaria as importações necessárias ao processo industrializante. Além do mais, o capital internacional estava disposto a investir na área, bastava que os governos locais assegurassem fatores como estabilidade política e econômica e incentivos físcais às empresas a serem instaladas.

Este artigo propõe analisar o turismo para além da racionalidade instrumental, como anteriormente exposto. A importação de modelos de desenvolvimento dos países desenvolvidos pode reproduzir o servilismo dos períodos anteriores. A geração de renda, propagada como benefício, pode ocorrer de forma desarmônica, de forma concentrada, excluindo a população local, que, por falta de capacitação e de organização política fica submetida a empregos operacionais e é destituída de poder decisório em relação à utilização dos recursos naturais, culturais e históricos da localidade. 
Países, como relatado por Arrones (1992), que adotaram o turismo perceberam, já na década de 1970, que o mesmo não era uma promessa rápida e certa de desenvolvimento. Muitos destinos de países de terceiro mundo são facilmente substituídos e regiões dependentes das rendas despendidas pelos turistas podem sofrer com a falta destes, aguçando as distorções já existentes.

Em muitas experiências, a comunidade não participa das decisões acerca da utilização e consumo dos atrativos turísticos, nem pode usufruir dos mesmos, em virtude do aumento do custo de vida das localidades turísticas. Os melhores empregos gerados nas organizações que exploram o turismo são geralmente ocupados por gestores externos ao lugar onde a organização está instalada e apenas os cargos operacionais são destinados à comunidade. Também, pode ocorrer a incorporação de hábitos de consumo incompatíveis com a realidade dos autóctones. De acordo com García (2005, p. 47):

El turismo es una industria que los gobiernos se encuentran ávidos de promover, pero que repercute negativamente en el desarrollo: desvía recursos sociales para invertir en infraestructura turística, sustrae mano de obra y acaba con la producción agrícola, concentra los beneficios en la comunidad empresarial y oligárquica, altera el valor de la tierra y propicia la especulación inmobiliaria, impone un valor comercial a cualquier objeto de arte o de antigüedad, mercantiliza la cultura, distorsiona la realidad con imágenes engañosas, amenaza el estilo de vida ingenuo de los nativos, trastoca los nexos morales de las comunidades anfitrionas y los convierte en nexos monetarios (particularmente con las relaciones sexuales y las tradicionales hospitalarias) y es claramente conservacionista al mantener el status quo para proteger la seguridad física del turista y financiera de las inversiones.

A atividade turística está inserida no contexto capitalista, através da ideologia do consumo, orientação no cliente e centralização na economia. Conforme Cruz (2002), a permanente necessidade de criação de novos produtos e, conseqüentemente, da expansão de consumidores faz do mercado um agente importante da apropriação de territórios para o uso do turismo, ou seja, de sua transformação em produto turístico.

A região litorânea nordestina está no centro das políticas públicas de turismo empreendidas e a criação e desenvolvimento de megaprojetos hoteleiros, proporcionou uma infra-estrutura 
territorialmente concentrada em áreas de interesse turístico. Essa concentração está de acordo com o pensamento de François Chesnais (1996, p. 17), para o qual "as operações feitas com finalidades lucrativas [...] são, por definição, seletivas", ou seja, não são todas as áreas do planeta que interessam ao capital, mas partes onde determinados critérios podem ser atendidos, como por exemplo, o de retorno financeiro.

Ao Estado, portanto, cabe a tarefa de selecionar, em primeiro lugar, os espaços que deverão ser contemplados com seus programas de desenvolvimento do turismo. No turismo, o neoliberalismo dita as regras de sua propagação no território ao buscar cenários ideais para o surgimento e concentração de megaempreendimentos turísticos, nacionais e internacionais, que visam atender os turistas de todas as partes do mundo. O investimento de empresas estrangeiras acompanha a internacionalização do turismo.

A implantação de grandes grupos empresariais não exclui completamente os pequenos empreendimentos, mas os confinam em papéis complementares, sem grande relevância (DUHAMEL; VIOLIER, 2009). O sistema estimula a formulação de políticas que tem a retórica de desenvolvimento e minimização de desigualdades sociais, mas que, na verdade, pode estimular o aprofundamento das desigualdades já existentes ao privilegiar apenas alguns setores produtivos e alguns grupos sociais.

Barbosa et al (2008a) ao analisarem os discursos de apresentação do Presidente Luiz Inácio Lula da Silva e da ex-ministra do Estado do Turismo, Marta Suplicy, no Plano Nacional de Turismo 2007-2010, plano norteador da atividade turística no Brasil, relatam que os discursos vislumbram a atividade como indutora do desenvolvimento e inclusão social, no entanto, as ações propostas contemplam prioritariamente os interesses da produção econômica e do mercado consumidor, e em último plano, as necessidades mais facilmente atendidas das comunidades receptoras.

Em Porto de Galinhas, por exemplo, litoral sul de Pernambuco, considerada por dez anos consecutivos como a melhor praia do país por uma importante revista especializada em turismo da editora Abril, essas distorções são bastante aparentes. O desenvolvimento do turismo intensificado no início da década de 1990 impulsionou o deslocamento da população nativa para locais mais distantes da praia e contribui para a migração de pessoas de municípios vizinhos atraídas pela possibilidade de emprego. Esse processo possibilitou o 
surgimento de três comunidades de baixa renda (denominadas de Socó, Salinas e Pantanal), onde estão localizadas mais de 2000 pessoas que vivem em palafitas situadas em locais próximos ou dentro dos manguezais e lagoas. De acordo com Melo (2006, p. 15),

não há banheiro na maioria das casas e os dejetos vão para os rios e lagoas. Não há controle e fiscalização sanitária e ambiental. Muitos dos moradores destas áreas trabalham na cadeia do turismo em setores formais (bares, hotéis, pousadas, e venda de artesanato) ou informais (ambulantes e biscateiros). São nestas comunidades que se concentram os bolsões de pobreza de Porto de Galinhas. Estes contrastam com o conforto dos hotéis, pousadas e das casas de veraneio.

O aumento crescente e acelerado de turistas, acompanhado da falta de ações efetivas de planejamento urbano, agravou os problemas existentes em Porto que se consolidou como destino receptor de turistas nacionais e com grande potencial internacional. A região foi alvo de importantes programas federais como o Programa Nacional de Municipalização do Turismo (PNMT), o Programa de Desenvolvimento do Turismo do Nordeste (PRODETUR/NE) e atualmente a região é um dos destinos indutores do turismo do Programa de Regionalização do Turismo do Plano Nacional de Turismo (PNT).

As intervenções, contudo, voltadas mais para questões econômicas - dotar o destino de infraestrutura de forma a atrair cada vez mais turistas, a permanência destes e o dispêndio realizado pelos mesmos - apesar do discurso de sustentabilidade, não foi capaz de minimizar os impactos decorrentes da atividade. Os seguintes problemas, evidenciados no quadro 1, foram evidenciados no relatório da Agência Estadual de Meio Ambiente do Estado de Pernambuco - CPRH, em 2003, e vem se agravando ao longo dos anos, como pode ser visto em reportagens publicadas em jornais locais (GUARDA, 2011; PEREIRA, 2011), e no diário oficial do estado de Pernambuco (PERNAMBUCO, 2007; 2009). 
Quadro 1 - Consequências negativas do desenvolvimento turístico desordenado em Porto

\begin{tabular}{|c|c|}
\hline DIMENSÕES & CONSEQUÊNCIAS \\
\hline $\begin{array}{l}\text { AMBIENTAIS, ECOLÓGICOS } \\
\text { e SOCIOCULTURAIS. }\end{array}$ & $\begin{array}{l}\text { - avanço das construções na faixa de praia } \\
\text { - } \text { obstrução, parcial ou total, dos acessos à praia; } \\
\text { - utilização descontrolada dos recifes de coral; } \\
\text { - privatização de áreas de uso público; } \\
\text { - abastecimento de água precário; } \\
\text { - falta de saneamento (rede de esgoto e de drenagem de águas } \\
\text { - coluviais); } \\
\text { - dos resíduos (em lixão); } \\
\text { - falta de sinalização nas praias; } \\
\text { - turísticos; } \\
\text { - trânsito caótico em fins de semana e feriados; } \\
\text { precariedade dos acessos viários. }\end{array}$ \\
\hline
\end{tabular}

Fonte: Elaborado a partir de CPRH (2003)

Do ponto de vista econômico, Porto de Galinhas, como tantas outras praias nordestinas, se destacam como destino turístico consolidado, contudo, como as outras dimensões da sustentabilidade que as políticas públicas pregam - a social e a ambiental - estão sendo equilibradas? O turismo, enquanto estratégia de desenvolvimento de comunidades deveria, de acordo com o discurso, ser capaz de melhorar as condições de vida da população e contribuir para a o desenvolvimento cultural de seus cidadãos, no entanto, os ganhos da atividade são desproporcionalmente distribuídos entre as organizações promotoras e a comunidade local.

Como foi explicado antes, este trabalho entende desenvolvimento para além da racionalidade instrumental, para além dos ganhos econômicos. Na transição do modelo agro-exportador para o industrial no país, em meados do século XX, o desenvolvimento nacional era visto como sinônimo de investimento nas forças produtivas. Atualmente, desenvolvimento não é o mesmo que crescimento econômico. $\mathrm{O}$ aumento das forças produtivas, segundo Furtado (2000, 2002) deve ser acompanhado pela melhoria do padrão de vida da população e por alterações na estrutura de sua economia. O crescimento econômico no Brasil é 
estruturalmente concentrador de renda e desarticulador da sociedade, contribuindo para a anomia da população quanto à percepção efetiva dos problemas sociais.

Segundo o Brasil (2007), 845,5 milhões de pessoas viajaram em 2006 no mundo, gerando uma receita de US\$ 732,8 bilhões. O Brasil ainda tem uma participação pequena nestes números, com 5 milhões de turistas, contribuiu com $0,59 \%$ do fluxo de turistas no mundo, e uma receita de 4,3 bilhões de dólares. Esses e outros dados estatísticos, contudo, têm sido utilizados como norteadores e impulsionadores de diversas políticas públicas e investimentos privados, sem ter sido analisada com mais profundidade a questão do desenvolvimento sustentável.

O desenvolvimento turístico, bem como outras políticas públicas, baseado na sustentabilidade faz em parte de uma orientação global de desenvolvimento, intensificada a partir dos trabalhos da Comissão Mundial sobre Meio Ambiente e Desenvolvimento, composta por representantes de países em desenvolvimento e de ONGs ambientalistas que culminaram com a publicação do Relatório Brundtland, em 1988, que formalizou o conceito de desenvolvimento sustentável como aquele que atende as necessidades do presente sem comprometer a possibilidade das gerações futuras atenderem às suas próprias necessidades (BRUNDTLAND, 1988).

O desenvolvimento, sinônimo de crescimento econômico, passou por uma crise de legitimidade e visto, utilizando as palavras de Brunel (2007) como contra-produtivo, pernicioso e ineficaz, foi gradualmente suplantado pela ideias de que o desenvolvimento deveria respeitar os recursos limitados e não renováveis do planeta, além de melhorar as condições de vida de todos.

A expressão turismo sustentável passa a ser usado com freqüência a partir da década de 1990 e foca um turismo que busca o equilíbrio entre as dimensões ambiental, social e econômica. Dentro desse contexto, o turismo deve ser, conforme o artigo 1 da Carta de Turismo, adotada pela Organização Mundial do Turismo em 1995, em Lazarote, “suportável ao longo prazo sob o plano ecológico; viável sob o plano econômico e equitativo sob o plano ético e social para as populações locais"8 (OMT, 1995). Como pode ser visto, a própria maneira de se fazer

\footnotetext{
${ }^{8}$ Do original: Il doit être supportable à long terme sur Le plan écologique, viable sur le plan économique et equitable sur le plan éthique et social pour les populations locales.
} 
turismo deve ser modificada pois não é aceitável que um turismo nocivo à região ao privilegiar apenas ou especialmente a dimensão econômica, seja valorizado e implementado com o apoio ou a omissão do Estado.

\section{Considerações Finais e Novos Direcionamentos de Pesquisa}

Conforme discussão e argumentação ao longo deste artigo, o potencial turístico enquanto vetor de desenvolvimento é uma possibilidade, todavia, as bases do modelo de desenvolvimento devem ser melhor analisadas e a visão acrítica da atividade deve ser evitada, pois, conforme Britton (1992), o turismo enquanto produtor de benefícios para muitos países do terceiro mundo, também pode perpetuar as desigualdades regionais e de classes, os problemas econômicos e as tensões sociais.

Os gestores privados e públicos devem ter o cuidado de analisar se determinada prática institucionalizada é importante e necessária para sua organização ou comunidade. Ramos (1965) discute o conceito de redução sociológica que implica em uma atitude metodológica que não admite a existência na realidade social de objetivos sem pressupostos e é traduzido em um procedimento crítico-assimilativo da experiência estrangeira. Essa atitude não implica isolacionismo, nem exaltação romântica, na visão do autor, do local, região ou nação, mas tão somente opor-se à prática de transplantações acríticas sem a utilização de apurados critérios de seletividade.

A implementação do turismo mais consciente das potencialidades e limites da região deve passar, conforme Caire e Caire-Roullet (2002), por um planejamento estratégico cujo processo decisório está baseado na reflexão, consulta e participação de todos os atores envolvidos. As orientações gerais da Organização Mundial do Turismo sobre a atividade turística estão baseadas na necessidade de que a comunidade local deveria ser inserida nas discussões sobre as opções de desenvolvimentos possíveis para decidir sobre as alternativas a serem adotadas. Caso contrário, os destinos do turismo serão conduzidos por atores e grupos que, na maioria das vezes, não refletem e não atendem os interesses da população local.

Diante do exposto, também, cabe questionar: será que o modelo de desenvolvimento turístico implementado no Nordeste brasileiro contribui para desenvolver a região? De que forma, por 
exemplo, o modelo de turismo que implica na construção de grandes resorts de praia, onde o contato dos turistas com a comunidade local é limitado contribui efetivamente para o tão "sonhado" desenvolvimento? Quem se beneficia com os investimentos do turismo de massa? Que interesses estão subjacentes ao clamor por maiores investimentos em grandes empreendimentos hoteleiros?

As ideias de Adorno e Horkheimer e dos outros pensadores da Escola de Frankfurt, como Marcuse, Benjamim e Habermas contribuem para refletir sobre outras possibilidades de ação para além da ciência positivista e da lógica de mercado que impera nas relações organizacionais e da sociedade. Essa discussão é importante por causa da força do pensamento dominante que impede a possibilidade de diálogo e com isso as massas absorvem de forma submissa as verdades da ciência positivista (ADORNO, HORKHEIMER, 1985).

Estudar as ideias da Escola de Frankfurt foi e será importante nessa trajetória de busca de aprofundamento sobre a temática abordada. A discussão possibilita entendimento de que a ciência social científica baseada em pressupostos das ciências naturais, onde tudo pode ser mensurado e quantificado, não pode ser padrão de verdade e de adequado conhecimento científico. As séries estatísticas que demonstram os "benefícios e os potenciais" do turismo devem ser melhor analisadas e comparadas com outros indicadores qualitativos. Estudar teoria crítica nos possibilita questionar a relação entre turismo e mercado e como essa relação se estabelece e se perpetua. Possibilita também entender que o turismo é um fenômeno historicamente situado e não deve ser analisado fora do contexto social existente e especialmente que o turismo deve estar integrado em um projeto global de desenvolvimento sustentável pois como este pode ser sustentável quando a própria sociedade e os setores com os quais ele se relacionada e interagem não o são?

\section{Referências}

ADORNO, Theodor. A indústria cultural. In: COHN, Gabriel (org.). Comunicação e indústria cultural. São Paulo: Companhia Editora Nacional/EDUSP, 1971. p. 287-295.

ADORNO, Theodor; HORKHEIMER, Max. A indústria cultural: o esclarecimento como mistificação das massas. In: Dialética do esclarecimento. Rio de Janeiro: Zahar Editores, 1985. p. 99-138.

ARCHER, Brian; COOPER, Chris. Os impactos positivos e negativos do turismo. In: THEOBALD, William F. (org). Turismo global. São Paulo: Editora SENAC, 2002. p. 85-102. 
ARRONES, Francisco Jurdão. Los mitos del turismo. In: ARRONES, Francisco Jurdão. Los mitos del turismo. Madrid: Endymion, 1992. p. 15-88.

ASSOUN, Paul-Laurent. L'ecole de Francfort. Paris, Presses Universitaires de France, 1990.

BACAL, Sarah. Lazer e o universo dos possiveis. São Paulo; Aleph, 2003.

BALDI, Mariana; LOPES, Fernando Dias. Turismo, desterritorialização e reteriorização: é preciso distinguir para quem e por quem? In: X Colóquio Internacional sobre Poder Local, 2006. Salvador. Anais... Salvador, 2006.

BALLESTER ROS, Ignácio. Desarrollo del turismo y crecimiento económico. Estudios Turísticos. Madrid : Instituto de Estudios Turísticos . n. 14; 1967. p. 7-91.

BARBOSA, Alba de Oliveira; MELO, Maristela Jorge; SILVA, Michelaine Machado Maciel. Análise bibliométrica da produção científica de turismo em administração. In: V Seminário de Pesquisa em Turismo no MERCOSUL, 2008, Caxias do Sul. Anais... Caxias do Sul: SeminTUR, 2008.

Desenvolvimento através do turismo: uma análise dos discursos de apresentação do PNT 2007-2010. In: V Seminário de Pesquisa em Turismo no MERCOSUL, 2008, Caxias do Sul. Anais... Caxias do Sul: SeminTUR, 2008a.

BDE-PE. Base de dados do Estado de Pernambuco. Dados sociais. Disponível em: < http://www.bde.pe.gov.br>. Acesso em 21 out. 2011.

BENI, Mário Carlos. Análise estrutural do turismo. São Paulo: Editora Senac, 2000.

BRASIL. Ministério do turismo. Estatísticas básicas de turismo. Brasília, nov. 2007. Disponível em: $<$ http://institucional.turismo.gov.br>. Acesso em: 14 fev. 2008.

Ministério do turismo. Plano Nacional do Turismo 2007-2010: uma viagem de inclusão. Brasília, 2007a. Disponível em: <http://institucional.turismo.gov.br>. Acesso em: 14 fev. 2008.

BRITTON, Stephen G. La economia política del turismo en el tercer mundo. In: ARRONES, Francisco Jurdão. Los mitos del turismo. Madrid: Endymion, 1992. p. 301-319.

BRONZO, Marcelo; GARCIA, Fernando Coutinho. As bases epistemológicas do pensamento administrativo convencional e a crítica à teoria das organizações. In: RODRIGUES, Suzana Braga; CUNHA, Miguel P. (org.) Estudos organizacionais: novas perspectivas na administração de empresas. Uma coletânea Luso-brasileira. São Paulo: Iglu, 2000.

BRUNDTLAND, Gro Harlem (coord.). Nuestro futuro común. Madrid: Alizana Editorial, 1988.

BRUNEL, Sylvie. Le développement durable. Paris: Presse Universitaires de France, 2007. Collection Que sais-je?

CAIRE G., ROULLET-CAIRE Monique. Le tourisme peut-il être un élément de développement durable ? In: Les enjeux du développement durable. Orcades, Poitiers, 2002. Disponible en: $<$ www.sceco.univ-poitiers.fr>. Acesso em 20 out. 2011.

CAZES, Georges; COURADE, Georges. Les masques du tourisme. Revue Tiers Monde. Paris, T. XLV, n. 178, p. 247-268, avril-juin, 2004. Disponível em: <www.persee.fr>. Acesso em: 20 mar. 2010.

CHESNAIS, François. A mundialização do capital. São Paulo: Xamã, 1996.

CPRH - AGÊNCIA ESTADUAL DE MEIO AMBIENTE DO ESTADO DE PERNAMBUCO. Diagnóstico socioambiental do litoral sul de Recife. 2003. Recife, 2003. Disponível em: $<$ www.cprh.pe.gov.br>. Acesso em 23 ago. 2010. 
CORIOLANO, Luzia Neide M. T. Da sedução do turismo ao turismo de sedução. In: RODRIGUES, Adyr Balastreri (org). Turismo: modernidade e globalização. São Paulo: Hucitec, 1999. p. 119-135.

CRICK, Malcolm. Representaciones del turismo internacional em las ciências sociales: sol, sexo, paisajes, ahorros y servilismos. In: ARRONES, Francisco Jurdão. Los mitos del turismo. Madrid: Endymion, 1992. p. 341-403.

CRUZ, Rita de Cássia. Política de turismo e território. São Paulo: Ed. Contexto, 2002.

DE KADT, Emmannuel. Turismo: pasaporte al desarrollo? Madrid: Ediciones Endymion, 1979.

DUHAMEL, Philippe; VIOLIER, Phillipe. Tourisme et littoral: un enjeu du monde. Belin: Paris, 2009.

FREITAG, Bárbara. A teoria crítica: ontem e hoje. São Paulo: Editora Brasiliense, 1990.

FRESSATO, Soleni. A teoria dialética de Adorno: possibilidades e limites do conhecimento de "indústria cultural". In: Encontro de Estudos Multidisciplinares em Cultura, 2007, Salvador. Anais...Salvador: ENECULT, 2007.

FURTADO, Celso. Em busca de novo modelo: reflexões sobre a crise contemporânea. São Paulo: Paz e Terra, 2002.

2000.

. Introdução ao desenvolvimento: enfoque histórico-estrutural. Rio de Janeiro: Paz e Terra,

GARCÍA, Maribel Osório. Hacia la construccion del objeto de estúdio del turismo desde uma perspectiva materialista critica. PASOS - Revista de Turismo e Patrimonio Cultural. Vol. 3, no. 1, 2005. p. 41-61.

GUARDA, Adriana. Documento 2011: SUAPE. Disponível em: $<$ http://www2.uol.com.br/JC/especial/suape/index.html . Acesso em 10 nov. 2011.

HORKHEIMER, M. Teoria tradicional e teoria crítica. In: BENJAMIN, W.; HORKHEIMER, M.; ADORNO, T.W.; HABERMAS, J. Textos escolhidos. São Paulo: Abril Cultural, 1980.

INSTITUTO BRASILEIRO DE GEOGRAFIA E ESTATISTICA - IBGE. Economia do turismo: análise das atividades características do turismo 2003-2006. Estudos e pesquisas. Informação Econômica, número 12. Rio de Janeiro, 2009. Disponível em: <www.ibge.gov.br>. Acesso em 18 jun. 2009

KRIPPENDORF, Jost. Sociologia do turismo: para uma nova compreensão do lazer e das viagens. Rio de Janeiro: Civilização Brasileira, 1989.

LAGE, Beatriz Helena Gelas; MILONE, Paulo Cesar. Impactos socioeconômicos globais do turismo. In: . Turismo: teoria e prática. São Paulo: Atlas, 2000. p. 117-131.

MELO, Maria Emília. Relatório de pesquisa. Sustentabilidade e responsabilidade social na cadeia do turismo: o caso da praia de Porto de Galinhas em Ipojuca-PE / Brasil. Rio de Janeiro, 2006. Disponível em: $\quad<$ http://somo.nl/publicationsen/Publication_2229/at_multi_download/files?name=Document\%20part>. Acesso em 10 ago. 2010.

OMT - Organisation Mondiale du Tourisme. Charte du tourisme durable. Lanzarote, Espagne. 27-28 abr. 1995. Disponível em: <http://unwto.org>. Acesso em 06 nov. 2011

PEREIRA, Nathalia. O lado sem glamour de Porto de Galinhas. Infraestrutura. Jornal do Commercio. On line. 18 out. 2011. Disponível em: <http://jconline.ne10.uol.com.br>. Acessoem 21 out. 2011.

PERNAMBUCO. Ata da audiência pública da Comissão de Desenvolvimento Econômico, realizada no dia 07 de novembro de 2007. Diário Oficial [do] Estado de Pernambuco, Poder Legislativo. 
Recife, PE, ano LXXXIV, n. 209, 20 nov. 2007. Disponível em: <www.cepe.com.br>. Acesso em 20 abr. 2011.

- Governo do Estado. Pernambuco para o Mundo: Plano estratégico de turismo de Pernambuco. Versão Pública. São Paulo: 2008.

Casa do governador: Eduardo e portugueses assinam contrato. Diário Oficial [do] Estado de Pernambuco, Poder Executivo. Recife, PE, ano LXXXV, n. 52, 18 mar. 2008a. Disponível em: $<$ www.cepe.com.br>. Acesso em 20 abr. 2011.

Turistas ameaçam recifes de corais. Diário Oficial [do] Estado de Pernambuco, Poder Legislativo. Recife, PE, ano LXXXVI, n. 211, 03 dez. 2009. Disponível em: <www.cepe.com.br>. Acesso em 20 abr. 2011.

RAMOS, Alberto Guerreiro. Definição e Descrição da Redução Sociológica. In: RAMOS, Alberto Guerreiro. A redução sociológica: introdução ao estudo da razão sociológica. Rio de Janeiro: Editora Tempo Brasileiro, 1965. p. 81-84.

. A nova ciência das organizações: uma reconceituação da riqueza das nações. Rio de Janeiro: Fundação Getúlio Vargas, 1989. $2^{\mathrm{a}}$ edição.

REJOWSKI, Mirian; SOLHA, Karina Toledo. Turismo em um cenário de mudanças. In: Rejowski, Mirian. (org) Turismo no percurso do tempo. São Paulo: Aleph, 2002. p. 75-122.

SALTO, Mónica Goded. El impacto del turismo sobre el desarrollo econômico: el caso de Argentina. Departamento de Economia Aplicada I. Economia Internacional y Desarrollo. Tesis (Doctoral). Universidade Complutense de Madrid: Madrid, 1998.

SANTOS FILHO, João dos. Ontologia do turismo. Caxias do Sul: EDUCS, 2005.

URRY, John. O olhar do turista: lazer e viagens nas sociedades contemporâneas. São Paulo: Studio Nobel: SESC, 1996.

WILLIAMS, Peter W.; GILL, Alison. Questões de gerenciamento da capacidade de carga turística. In: THEOBALD, William F. (org). Turismo global. São Paulo: Editora SENAC, 2002. p. 245-260.

\section{Recebido em: 13/04/2011}

Aprovado em: 29/11/2011 (1 ${ }^{\text {a }}$ versão) $20 / 12 / 2011$ ( $2^{\text {a }}$ versão) 